\title{
Response of surface ozone concentration to emission reduction and meteorology during the COVID-19 lockdown in Europe
}

\author{
Adrien Deroubaix $^{1} \odot$ | Guy Brasseur ${ }^{1,2}$ () | Benjamin Gaubert ${ }^{2} \odot$ ।

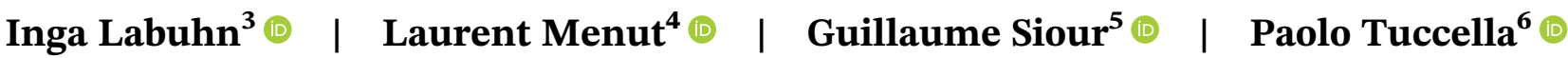

\author{
${ }^{1}$ Max Planck Institute for Meteorology, \\ Hamburg, Germany \\ ${ }^{2}$ Atmospheric Chemistry Observations \& \\ Modeling Laboratory (ACOM), National \\ Center for Atmospheric Research, \\ Boulder, CO, USA \\ ${ }^{3}$ University of Bremen, Institute of \\ Geography, Bremen, Germany \\ ${ }^{4}$ LMD/IPSL, Ecole Polytechnique, \\ Université Paris Saclay, ENS, IPSL \\ Research University; Sorbonne Université, \\ CNRS, Palaiseau, France \\ ${ }^{5}$ Laboratoire Interuniversitaire des \\ Systèmes Atmosphériques (LISA), UMR \\ CNRS 7583, Université Paris Est Créteil et \\ Université de Paris, Institut Pierre Simon \\ Laplace, Créteil, France \\ ${ }^{6}$ Departement of Physical and Chemical \\ Sciences, University of L'Aquila, L'Aquila, \\ Italy

\section{Correspondence} \\ Adrien Deroubaix, Max Planck Institute \\ for Meteorology, Hamburg, Germany. \\ Email: adrien.deroubaix@mpimet.mpg.de \\ Funding information
}

Max-Planck-Gesellschaft

\begin{abstract}
The lockdown period (March-May 2020) during the COVID-19 pandemic in Europe led to a reduction in the anthropogenic emissions of primary pollutants. For three-quarters of over 1,100 available monitoring stations, the average nitrogen dioxide $\left(\mathrm{NO}_{2}\right)$ concentrations decreased by at least $2.7 \mu \mathrm{g} \cdot \mathrm{m}^{-3}$ (or 25\%) compared with the average concentrations recorded during the same period of the previous seven years. This reduction was not specific to urban or rural areas because the relative reduction was of similar magnitude in both areas. The ozone $\left(\mathrm{O}_{3}\right)$ response differed spatially, with positive anomalies in Northern Europe and negative anomalies in Southwestern Europe. Reduced cloudiness and related enhanced radiation in Northern Europe played a significant role in the increase of surface $\mathrm{O}_{3}$ concentrations by shifting the photochemical partitioning between $\mathrm{NO}_{2}$ and $\mathrm{O}_{3}$ toward more $\mathrm{O}_{3}$. The level of total oxidant $\left(\mathrm{O}_{\mathrm{x}}=\mathrm{O}_{3}+\mathrm{NO}_{2}\right)$ remained unchanged, except in Southwestern Europe where it decreased. Several episodes lasting a few days of a high level of total oxidants were observed in Northern Europe. The results illustrate the complexity of the atmospheric response to the unprecedented reduction in the emission of primary pollutants.
\end{abstract}

\section{K E Y W O R D S}

air quality, COVID-19, Europe, ozone, sensor networks, topo-climate, urban

\section{1 | INTRODUCTION}

COVID-19 lockdown restrictions were imposed worldwide in early 2020, first in China, starting in January 2020, and then in early and mid-March across Europe. In mid-May, restrictions started to be gradually lifted in Europe. Consequently, anthropogenic emissions, especially those related to traffic, were substantially reduced first in China (Le et al., 2020; Shi and Brasseur, 2020) and later elsewhere. The concentration of nitrogen dioxide $\left(\mathrm{NO}_{2}\right)$ observed at monitoring stations decreased by up to $60 \%$, whereas a simultaneous increase in ozone $\left(\mathrm{O}_{3}\right)$ concentration by a factor 1.5-2 was reported (Shi and Brasseur, 2020). Moreover, unexpected increases of sulfur dioxide $\left(\mathrm{SO}_{2}\right)$ were

This is an open access article under the terms of the Creative Commons Attribution-NonCommercial-NoDerivs License, which permits use and distribution in any medium, provided the original work is properly cited, the use is non-commercial and no modifications or adaptations are made.

(C) 2021 The Authors. Meteorological Applications published by John Wiley \& Sons Ltd on behalf of the Royal Meteorological Society. 
monitored during the lockdown period in some regions of China (e.g. the region of Hangzhou), probably due to higher coal consumption for heating (Wang et al., 2020).

Substantial changes in $\mathrm{NO}_{2}$ columns measured by the spaceborne TROPOMI instrument have been reported at locations with heavy lockdown measures due to the COVID-19 pandemic. In many Chinese cities, $\mathrm{NO}_{2}$ column densities decreased by at least $40 \%$ (Bauwens et al., 2020). In North American and European cities, a decrease of up to $40 \%$ was observed (Bauwens et al., 2020). In Spain, for example, the average reduction of $\mathrm{NO}_{2}$ during the lockdown compared with a "businessas-usual" emission scenario was estimated to be close to $40 \%$ using machine learning fed by meteorological data (Petetin et al., 2020).

Disentangling the lockdown effects on $\mathrm{NO}_{2}$ from the natural variability induced by meteorological conditions is essential to build accurate emissions for air quality modeling (Goldberg et al., 2020). Further, short-term perturbations of $\mathrm{NO}_{2}$ must be put in the context of the longterm trends of pollutant concentrations. Over the two last decades, $\mathrm{NO}_{2}$ trends have been negative in Europe, while $\mathrm{O}_{3}$ concentrations remained high (Colette et al., 2015; Yan et al., 2019).

Ordóñez et al. (2020) showed that the $\mathrm{O}_{3}$ concentration increased in Europe during the lockdown, except in the Iberian Peninsula and in southwestern areas of France. Using general additive models at each monitoring station to attribute the changes in surface $\mathrm{O}_{3}$ concentrations, they conclude that the meteorological variability outweighed the effects of emission reductions in both urban and rural areas.

The numerous links between $\mathrm{O}_{3}$ formation and meteorology, involving several processes, raise questions about the meteorological influence on the oxidation capacity of the low troposphere, especially in urban areas where $\mathrm{NO}_{2}$ reductions were largest (Kroll et al., 2020). Moreover, based on a modelling study, Menut et al. (2020) demonstrated that the $\mathrm{O}_{3}$ perturbation during the lockdown period was different in urban areas throughout Western Europe due to nonlinear chemical effects. This is further highlighted by Sicard et al. (2020) who showed a variable $\mathrm{O}_{3}$ increase in four Southern European cities (Nice in France, Rome and Turin in Italy, and Valencia in Spain), ranging from $2.4 \%$ in Valencia to $27 \%$ in Turin compared with the period 2017-2019. The purpose of the present study is to understand the causes of the surface $\mathrm{O}_{3}$ concentration change in response to the exceptional short-term reduction of anthropogenic emissions during the COVID-19 lockdown period in Europe. Anomalies are characterized in the concentrations of five regulated pollutants: carbon monoxide $(\mathrm{CO}), \mathrm{NO}_{2}, \mathrm{SO}_{2}$, $\mathrm{O}_{3}$ and particulate matter $\left(\mathrm{PM}_{10}\right)$ in rural and urban environments (compared with the previous seven years) associated with anomalies of different meteorological variables. This allows the investigation of the possible causes of the observed $\mathrm{O}_{3}$ concentration changes, which could be related to the changes in primary pollutant emissions, but also to concomitant changes in meteorology and photochemistry. The study will further focus on the evolution of the total oxidant concentrations (also called odd oxygen), that is, $\mathrm{O}_{\mathrm{x}} \approx \mathrm{O}_{3}+\mathrm{NO}_{2}$ (Wang and Jacob, 1998).

The study is based on measurements made at surface monitoring stations together with modelled meteorological conditions. Air quality data and other data sources are referred to in Section 2. Section 3 presents the distribution of the concentration changes, and Section 4 their spatial patterns. The $\mathrm{O}_{3}$ response is analysed in Section 5, and its consequences on the total oxidant level in Section 6. A discussion and perspectives are given in Section 7.

\section{I DATA AND METHODS}

Air quality, meteorological conditions and population density data were obtained for the spatial domain under consideration that extends from $11^{\circ} \mathrm{W}$ to $19^{\circ} \mathrm{E}$ and from $35^{\circ}$ to $60^{\circ} \mathrm{N}$. The focus here is on the period March 18May 18 of 2013-2020.

Measured concentrations of regulated pollutants from national monitoring networks were retrieved from the European Air Quality e-Reporting database (AirBase), which provides near-real-time air-quality data for Europe in a standardized format (AQ e-Reporting, 2020). The data available are hourly concentrations in the case of $\mathrm{CO}, \mathrm{NO}_{2}, \mathrm{SO}_{2}$ and $\mathrm{O}_{3}$, and daily concentrations in the case of $\mathrm{PM}_{10}$. The domain includes 1,680 AirBase stations. However, data from 1,308 stations were used the present study as stations were only selected with at least $70 \%$ of days of the period March 18-May 18 (for each year) filled with at least one hourly value for the respective pollutant.

Meteorological variables were obtained from the European Centre for Medium-Range Weather Forecasts' (ECMWF) Copernicus Atmosphere Monitoring Service (CAMS) global forecast at a horizontal resolution of approximately $40 \mathrm{~km}$ (T511 spectral) on 137 vertical levels from the surface up to $0.1 \mathrm{hPa}$. Through the CAMS global archived analysis and forecast daily data, $6 \mathrm{hr}$ analyses of the following meteorological variables were downloaded (Inness et al., 2019): $2 \mathrm{~m}$ temperature, $2 \mathrm{~m}$ dew point, mean sea level pressure, potential vorticity at $300 \mathrm{hPa}, 10 \mathrm{~m}$ zonal wind, $10 \mathrm{~m}$ meridional wind, total cloud cover and downward surface solar radiation (forecast accumulated over $24 \mathrm{hr}$ ). The $2 \mathrm{~m}$ relative humidity 
field was calculated on the basis of the temperature and dew point fields. The $10 \mathrm{~m}$ wind speed field was calculated from the zonal and meridional wind fields. The potential vorticity at $300 \mathrm{hPa}$ was selected as a proxy for the downward stratospheric transport (e.g. Doche et al., 2014).

Population density data were taken from the Gridded Population of the World Version 3 (GPWv3) data set, which has a spatial resolution of $1 \times 1 \mathrm{~km}$ (CIESIN/ CIAT, 2005; it is presented over the studied domain in Figure S1 in Appendix S1 in the additional supporting information). "Urban" and "rural" station types were defined based on the European Union's "high-density areas" threshold of 1,500 inhabitants. $\mathrm{km}^{2}$. This leads to 485 "urban" stations (above this threshold) and 1,195 "rural" stations (below this threshold). With this methodology, urban sites are clearly located in areas with high anthropogenic emissions, whereas rural sites include a large diversity of environments.

Temporal anomalies were analysed by comparing the atmospheric quantities for the period March 18-May 18, 2020 (i.e. the lockdown period) with the same quantities for the previous seven years (2013-2019). For pollutants, two metrics were used to characterize the chemical environment at each station location using hourly measurements: (1) mean concentrations; and (2) the median of the hourly daily maximum concentrations. Anomalies are expressed as absolute and relative differences between 2020 and the 2013-2019 average.

\section{3 | CHANGES IN THE CONCENTRATIONS OF REGULATED POLLUTANTS}

At each station, the mean concentrations of regulated pollutants during the lockdown period were compared with the mean concentrations of the same pollutants averaged over the previous seven years. The distribution of absolute and relative differences (i.e. anomalies) given by five percentiles (10th, 25th, 50th, 75th, 90th) are presented for all stations (Table 1) and with a distinction between urban and rural stations (see Tables S1 and S2 in Appendix S1 in the additional supporting information).

Note the clear reduction in the average concentrations of $\mathrm{NO}_{2}$, for which even the 90th percentile of the anomalies is negative (Table 1). Thus, at least $90 \%$ of the stations (P10) have monitored a reduction in $\mathrm{NO}_{2}$ concentrations of at least $1 \mu \mathrm{g} \cdot \mathrm{m}^{-3}$, or $14 \%$. In the case of $\mathrm{O}_{3}$, the median (P50) of the anomalies is positive $\left(4.3 \mu \mathrm{g} \cdot \mathrm{m}^{-3}\right.$, or $7 \%$ ), which means that a majority of the available stations have reported an increase in the average concentration. For $\mathrm{PM}_{10}$, the median (50th percentile) of the anomalies is slightly negative $\left(-0.7 \mu \mathrm{g} \cdot \mathrm{m}^{-3}\right.$, or $\left.-4 \%\right)$, and the 75 th percentile (P75) is positive $\left(1.6 \mu \mathrm{g} \cdot \mathrm{m}^{-3}\right.$, or $\left.-6 \%\right)$. Note that on March 28, a severe dust event over Southeast Europe led to strong positive $\mathrm{PM}_{10}$ anomalies for three days (Menut et al., 2020).

The present authors' confidence in the database to represent accurately the distribution of the concentration anomalies across Europe is high for $\mathrm{NO}_{2}$ and $\mathrm{O}_{3}$ because $71 \%$ and $68 \%$ of the stations provide data (i.e. 1,196 and 1,148 stations, respectively), and to a lesser extent for $\mathrm{PM}_{10}$ with $53 \%$ (i.e. 895 stations).

For $\mathrm{CO}$ and $\mathrm{SO}_{2}$, the number of monitoring stations is low (12\% and 27\%). Nevertheless, it can be observed that the median of the anomalies is $-13.5 \mu \mathrm{g} \cdot \mathrm{m}^{-3}(-5 \%)$ for $\mathrm{CO}$ and $-0.2 \mu \mathrm{g} \cdot \mathrm{m}^{-3}(-11 \%)$ for $\mathrm{SO}_{2}$. Note that the 75th and 90th percentiles of $\mathrm{CO}$ and $\mathrm{SO}_{2}$ are positive (Table 1), which shows that, in some regions, $\mathrm{NO}_{2}$ decreased while $\mathrm{CO}$ and $\mathrm{SO}_{2}$ increased. This suggests that traffic decreased while other emission sources such as residential or industrial emissions increased.

It can be expected that the strongest reduction in concentrations of primary pollutants happen in areas where human activities are the most intense. In other words, the reduction may be stronger at urban stations than at

TA B LE 1 Anomalies of the mean concentrations of carbon monoxide (CO), nitrogen dioxide $\left(\mathrm{NO}_{2}\right)$, sulfur dioxide $\left(\mathrm{SO}_{2}\right)$, ozone $\left(\mathrm{O}_{3}\right)$ and particulate matter $\left(\mathrm{PM}_{10}\right)$ in 2020 compared with the average of the previous seven years (2013-2019) for the period March 18-May 18, 2020, measured at 1,308 European Air Quality e-Reporting database (AirBase) stations

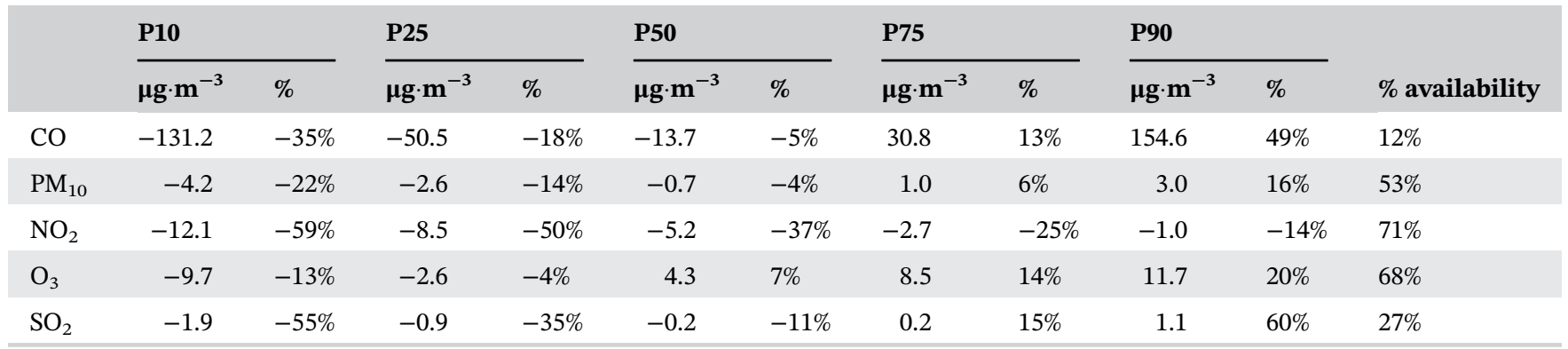

Note: The distribution of the anomalies for all stations is given by five percentiles (P10, P25, P50, P75, P90); “\% availability" indicates the percentage of available stations. Anomalies are presented in terms of concentrations $\left(\mu \mathrm{g} \cdot \mathrm{m}^{-3}\right)$ and of relative change $(\%)$ against the seven year average. 
rural stations. To test this hypothesis, the same analysis is performed separately for urban and rural stations (as defined in Section 2) to investigate the pollutant concentration changes depending on population density.

The analysis reveals that the relative concentration changes are very similar for urban and rural stations (see Tables S1 and S2 in Appendix S1 in the additional supporting information). As expected, the $\mathrm{NO}_{2}$ absolute anomalies are highest for urban stations $\left(-7.9 \mu \mathrm{g} \cdot \mathrm{m}^{-3}\right)$ compared with rural stations $\left(-3.9 \mu \mathrm{g} \cdot \mathrm{m}^{-3}\right)$, but the relative changes are similar for both types of stations $(-40 \%$ for urban and $-35 \%$ for rural stations). This result suggests that the mobility restrictions have led to comparable relative reductions of $\mathrm{NO}_{2}$ emissions in urban and rural areas.

The $\mathrm{O}_{3}$ absolute anomalies show an increase for both urban $\left(6.8 \mu \mathrm{g} \cdot \mathrm{m}^{-3}\right)$ and rural stations $\left(3.1 \mu \mathrm{g} \cdot \mathrm{m}^{-3}\right)$, although the relative anomalies show a comparable increase for those two areas (11\% in urban stations and $5 \%$ in rural stations). This result clearly suggests that areas with stronger reduction in $\mathrm{NO}_{2}$ concentrations led to higher increase in $\mathrm{O}_{3}$ concentrations. It is concluded that a clear reduction of the $\mathrm{NO}_{2}$ concentration averages was monitored during the lockdown period, but this is not the case for $\mathrm{O}_{3}$ and $\mathrm{PM}_{10}$ concentrations.

\section{I SPATIAL PATTERNS OF NO $\mathrm{AND} \mathrm{O}_{3}$}

Although the analysis shows that there are distinct pictures for $\mathrm{NO}_{2}$ and $\mathrm{O}_{3}$ concentrations during the lockdown period, it was investigated whether there were spatial discrepancies for $\mathrm{NO}_{2}, \mathrm{O}_{3}$ and $\mathrm{PM}_{10}$ anomalies calculated over the period March 18-May 18, 2020. Following the same methodology, the absolute and relative differences between 2020 and the previous seven years are presented in a single figure, where the information on maps where each station is coloured depends on absolute differences and is sized based on the relative differences.

The $\mathrm{NO}_{2}$ anomalies depict a clear reduction in mean concentrations (mostly $>30 \%$ ) during the lockdown all over Europe (Figure 1a). The strongest changes occur in Southern Europe (Spain, France, Italy) where the (a) $\mathrm{NO}_{2}$ mean concentration
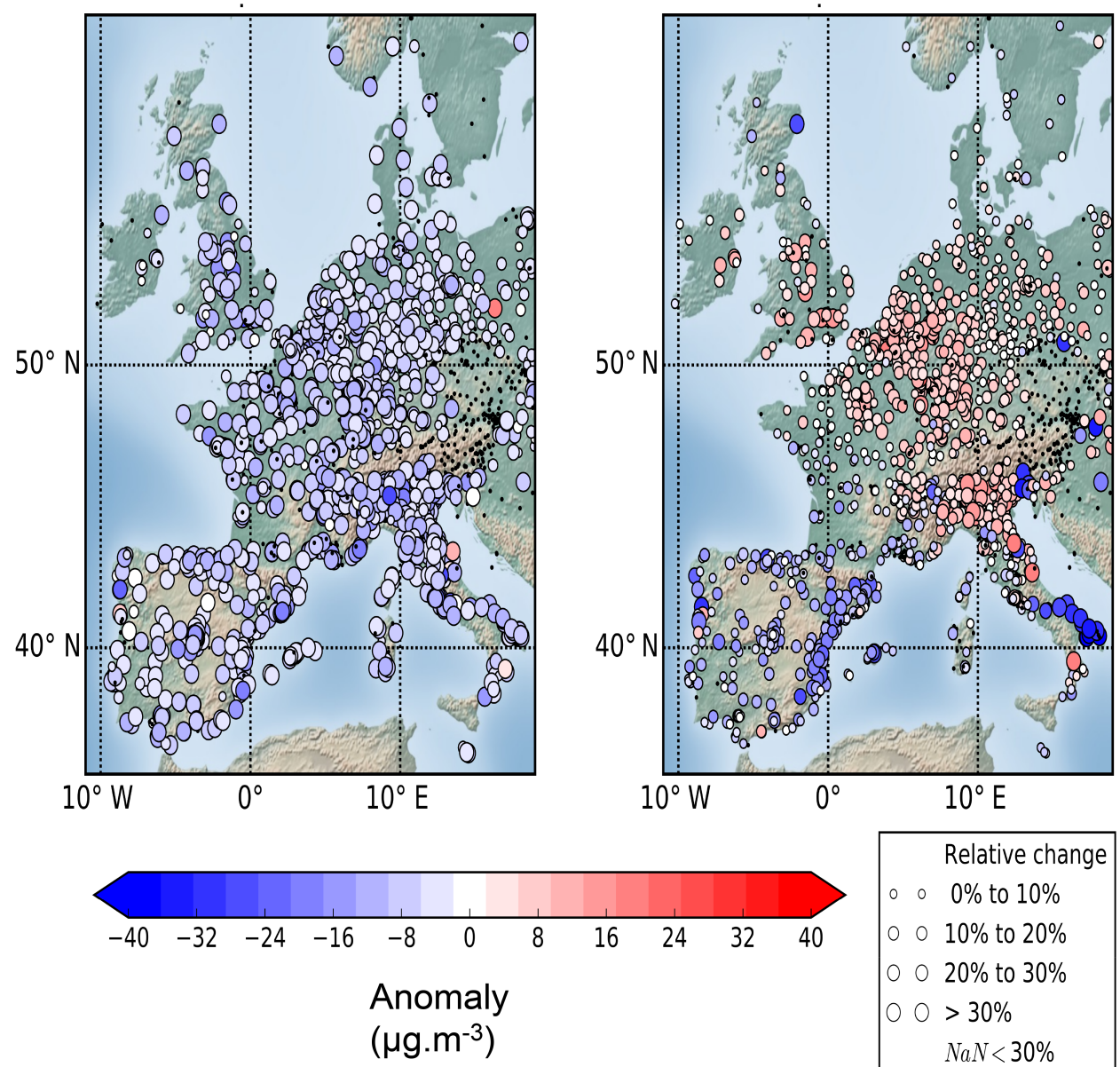

\section{(b) $\mathbf{O}_{3}$ mean concentration}

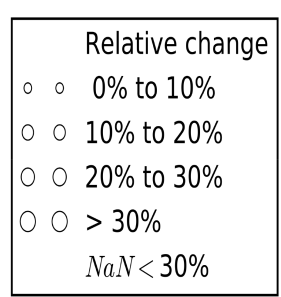

FIG URE 1 Anomalies of (a) nitrogen dioxide $\left(\mathrm{NO}_{2}\right)$ mean concentration and (b) ozone $\left(\mathrm{O}_{3}\right)$ mean concentration at European Air Quality e-Reporting database (AirBase) stations in 2020 compared with the previous seven years (2013-2019) for the period March 18-May 18, 2020. Dots are coloured according to the anomalies in concentration $\left(\mu \mathrm{g} \cdot \mathrm{m}^{-3}\right.$ ) and sized proportionally to the relative change (\%). Black dots correspond to stations with $<30 \%$ of available data 
COVID-19 incidence has been among the highest (COVID-19.who.int), and where the strongest mobility restrictions were imposed. At two stations (see Figure S2 in Appendix $\mathrm{S} 1$ in the additional supporting information), the $\mathrm{NO}_{2}$ concentrations are surprisingly greater in 2020 than during the seven previous years (anomaly $>10 \mu \mathrm{g} \cdot \mathrm{m}^{-3}$ ), which suggests recent increases in local emissions. Anomalies of the 50th percentile (median) and 90th percentile (P90) of daily maximum concentrations show the same spatial patterns (see Figure S3a and $\mathrm{S} 3 \mathrm{c}$ in Appendix $\mathrm{S} 1$ in the additional supporting information).

Although the negative anomalies in $\mathrm{NO}_{2}$ concentration occurred everywhere in Europe, regional patterns in $\mathrm{O}_{3}$, with positive anomalies in the Benelux and negative anomalies in Spain, Portugal and southwestern France, can be clearly observed (Figure 1b). In the north of the continent, most of the stations reported positive anomalies in the mean concentrations (ranging from $0 \%$ to 30\%), whereas in Southwestern Europe, negative anomalies were reported (ranging from $0 \%$ to $-30 \%$ ). In the region of the French and Italian Alps, the anomalies of $\mathrm{O}_{3}$ were especially variable $(>30 \%$ and $<-30 \%$ ).

As for $\mathrm{NO}_{2}$, anomalies in the 50th percentile (median) and 90th percentile (P90) of $\mathrm{O}_{3}$ daily maximum concentrations are characterized by the same spatial patterns as the anomalies of the mean concentrations (see Figure S3b and S3d in Appendix S1 in the additional supporting information).

It was checked if the spatial patterns of $\mathrm{PM}_{10}$ anomalies could be related to the patterns of $\mathrm{NO}_{2}$ and $\mathrm{O}_{3}$. Negative $\mathrm{PM}_{10}$ anomalies in the mean and median of daily maximum concentrations in Northern and Southwestern Europe were found (see Figure S4 in Appendix S1 in the additional supporting information). In Italy and Benelux, there was no spatially consistent pattern in $\mathrm{PM}_{10}$ anomalies. Thus, $\mathrm{PM}_{10}$ anomalies do not match those of $\mathrm{NO}_{2}$ and $\mathrm{O}_{3}$.

The investigations are consistent with Ordóñez et al. (2020) in terms of spatial patterns and quantification of the $\mathrm{O}_{3}$ anomalies, although they use a different methodology, reference period and definition of the lockdown duration. The contrast in $\mathrm{O}_{3}$ anomalies between the North and Southwest of Europe does not correspond to the spatial patterns in the $\mathrm{PM}_{10}$ anomalies nor to the level of urbanization. Therefore, further analysis on the $\mathrm{O}_{3}$ response is necessary, which is presented in the next section.

\section{5 | O $_{3}$ RESPONSE ANALYSIS}

A comprehensive analysis of the $\mathrm{O}_{3}$ response to the emission reduction of air pollutants during the COVID-19 lockdown must consider the different potential drivers of $\mathrm{O}_{3}$ changes. These include the emissions of precursor species such as $\mathrm{NO}_{\mathrm{x}}, \mathrm{CO}$ and volatile organic carbon (VOC), as well as surface dry deposition, together with the meteorological situation (atmospheric humidity and temperature, cloudiness and solar irradiance, precipitation, wind direction and speed, and intrusion of stratospheric air masses) (e.g. Monks et al., 2015). The analysis must also distinguish between regional (background) and local (urban) contributions.

The contribution of each process could not be quantified with the available data sets, but some evidence for the relative importance of their influence can be obtained. To document the spatial patterns of $\mathrm{O}_{3}$ anomalies in Europe, the study analyses: (1) the transport of $\mathrm{O}_{3}$ in Western Europe, (2) the meteorological disturbances, (3) the differences between urban and rural stations and (4) the relationship with $\mathrm{NO}_{2}$ anomalies.

The study investigates modifications on the western border of the domain by examining observations at the "Mace head" station, a site representative of the baseline $\mathrm{O}_{3}$ concentrations in the Northern Hemisphere at midlatitude (Derwent et al., 2018). During the period under investigation, the $\mathrm{O}_{3}$ concentration was in the range of the observations in the previous seven years (see Figure S5 in Appendix S1 in the additional supporting information). A modeling study supports the conclusion that the eastward transport of $\mathrm{O}_{3}$ in the lowermost troposphere was slightly reduced during the study period (Gaubert et al., 2020). In addition, another study based on $\mathrm{O}_{3}$ stations also reported a decrease of $7 \%$ from 1 to $8 \mathrm{~km}$ in altitude (Steinbrecht et al., 2020). The results and these studies indicate that the $\mathrm{O}_{3}$ anomalies in Europe were not driven primarily by a change in background $\mathrm{O}_{3}$, but rather by meteorological and emission changes.

During the lockdown period, the meteorology in Northern Europe, especially in the Benelux region, was characterized by anomalously low humidity (see Figure S6b and S6c in Appendix S1 in the additional supporting information), high pressure (see Figure S6d online), low cloudiness (Figure 2a), low wind speed (see Figures S6f, S6g and S6h online), high surface solar radiation (see Figure S6i online), and downward transport of air from the stratosphere (see Figure S6e online). These meteorological conditions are responsible for an enhancement in the $\mathrm{O}_{3}$ concentration due to the increase in surface solar radiation and low humidity in the planetary boundary layer (Yu, 2019). A positive anomaly in the $2 \mathrm{~m}$ temperature was observed in France, south of the dry anomaly region (see Figure S6a online). In Southern Europe, specifically Spain, where $\mathrm{O}_{3}$ concentrations were anomalously low, total cloud cover and relative humidity were particularly high and associated with low solar 

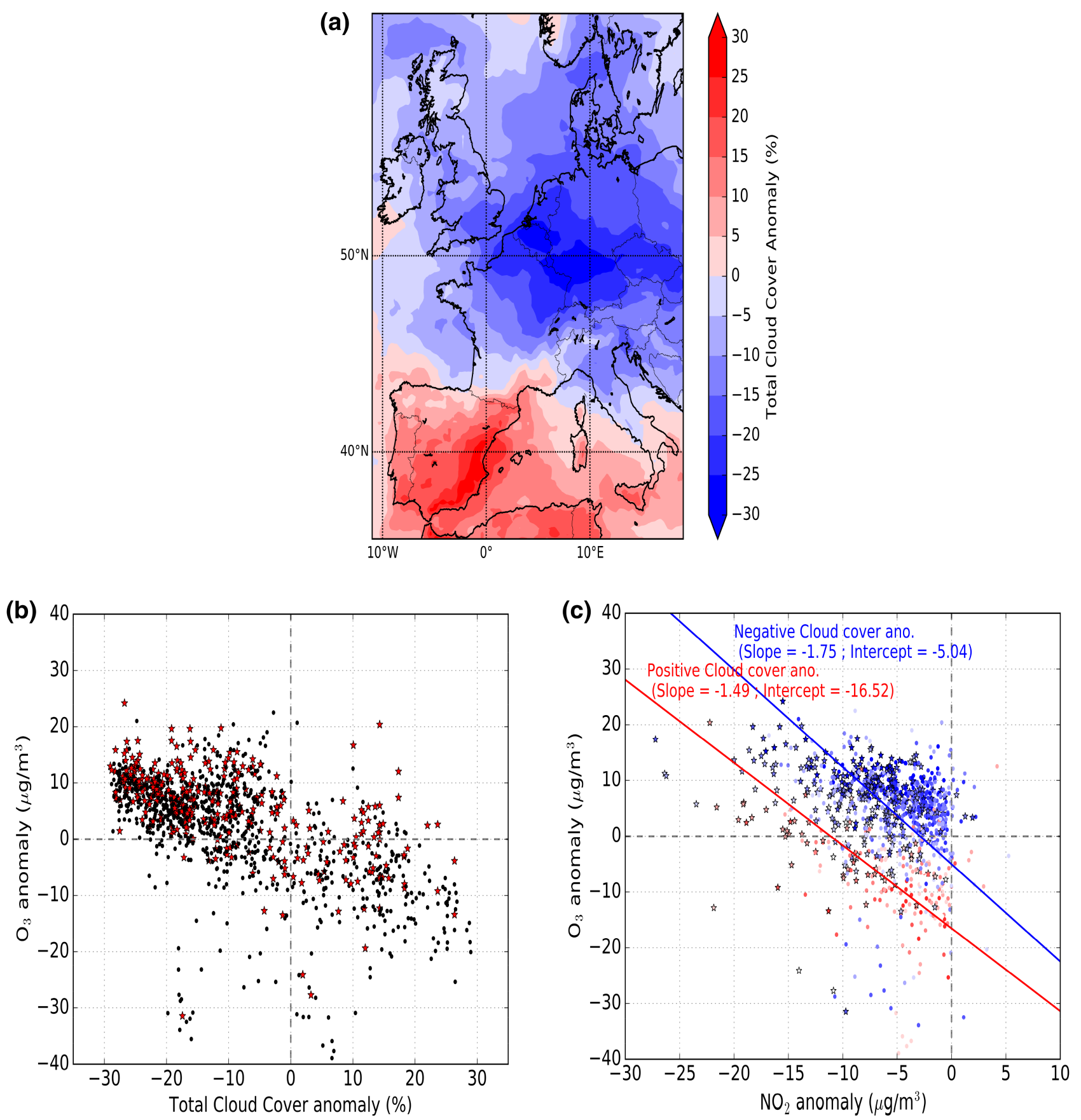

F I G U RE 2 (a) Total cloud cover anomalies from the Copernicus Atmosphere Monitoring Service (CAMS) global forecast. Anomalies of the means in 2020 compared with the previous seven years (2013-2019) for the period March 18-May 18, 2020. (b) Ozone $\left(\mathrm{O}_{3}\right)$ anomalies against total cloud cover anomalies at European Air Quality e-Reporting database (AirBase) stations. (c) $\mathrm{O}_{3}$ anomalies against nitrogen dioxide $\left(\mathrm{NO}_{2}\right)$ anomalies at AirBase stations. Stars in (b, c) represent "urban" stations; dots represent "rural" stations. "Urban" stations are defined by a population density threshold of 1,500 inhabitants $\mathrm{km}^{-2}$. Dots and stars in (c) are coloured depending on total cloud cover anomalies of (a) at each station. Blue and red lines are obtained by reduced major-axis regression restricted to positive and negative anomalies, respectively

radiation and temperature compared with the previous seven years.

The spatial patterns of several meteorological anomalies seem to match the $\mathrm{O}_{3}$ anomalies. The study analyses, therefore, the correlation co-efficients of the anomalies in the $\mathrm{O}_{3}$ concentrations against the anomalies of 10 meteorological variables at each site (i.e. the corresponding grid cell). Correlation co-efficients were calculated for all monitoring stations, as well as for urban and rural stations separately (Table 2). 
TA B L E 2 Correlation co-efficients $(R)$ between ozone $\left(\mathrm{O}_{3}\right)$ mean concentration anomalies and anomalies in (1) $2 \mathrm{~m}$ temperature, (2) $2 \mathrm{~m}$ dew point, (3) $2 \mathrm{~m}$ relative humidity, (4) mean sea level pressure, (5) potential vorticity at $300 \mathrm{hPa}$, (6) $10 \mathrm{~m}$ zonal wind speed, (7) $10 \mathrm{~m}$ meridional wind speed, (8) $10 \mathrm{~m}$ wind speed, (9) total cloud cover and (10) downward surface solar radiation

\begin{tabular}{|lrcr} 
& \multicolumn{3}{c}{ Mean $\mathbf{O}_{\mathbf{3}}$ anomalies } \\
\cline { 2 - 5 } $\boldsymbol{R}$ & \multicolumn{1}{c}{ All } & Urban & Rural \\
\hline 2 m-T ano. & 0.20 & 0.14 & 0.18 \\
\hline 2 m-Dew point ano. & -0.42 & -0.46 & -0.43 \\
\hline $\mathbf{2}$ m-RH ano. & $\mathbf{- 0 . 5 4}$ & $\mathbf{- 0 . 5 6}$ & $\mathbf{- 0 . 5 4}$ \\
\hline Pot. Vort. 300 hPa ano. & 0.43 & 0.47 & 0.44 \\
\hline MSL press. ano. & -0.35 & -0.37 & -0.33 \\
\hline 10 m-Zonal wind ano. & -0.15 & -0.19 & -0.09 \\
\hline 10 m-Merid. Wind ano. & -0.33 & -0.42 & -0.28 \\
\hline 10 m-Wind speed ano. & 0.25 & 0.24 & 0.26 \\
\hline Tot. cloud cov. ano. & $\mathbf{- 0 . 6 1}$ & $\mathbf{- 0 . 5 8}$ & $-\mathbf{0 . 6 1}$ \\
\hline Surf. solar rad. down. ano. & $\mathbf{0 . 5 9}$ & $\mathbf{0 . 5 8}$ & $\mathbf{0 . 6 0}$ \\
\hline
\end{tabular}

Note: Anomalies are calculated for 2020 compared with the previous seven years (2013-2019) for the period March 18-May 18, 2020. The distinction between "urban" and "rural" sites is defined by a population density threshold of 1,500 inhabitants $\mathrm{km}^{-2}$. Shown in bold font are $R>0.5$ or $<-0.5$.

The signs of these correlation co-efficients (i.e. $R$ ) are consistent with the interpretation that specific meteorological conditions (less clouds, higher radiation, lower humidity, higher pressure) lead to an increase in the $\mathrm{O}_{3}$ concentration. The spatial variability of the $\mathrm{O}_{3}$ anomalies explained with meteorological variable anomalies (i.e. $\left.R^{2}\right)$ are highest for the total cloud cover $\left(R^{2}=0.36\right)$, downward surface solar radiation $\left(R^{2}=0.35\right)$ and $2 \mathrm{~m}$ relative humidity $\left(R^{2}=0.30\right)$. Thus, the spatial variability of these meteorological anomalies is highly related with the spatial variability of $\mathrm{O}_{3}$ anomalies (i.e. $R^{2}=0.30-0.36$ ).

The correlation co-efficients between the $\mathrm{O}_{3}$ anomalies against meteorological anomalies are similar for urban and rural sites (Table 2), which suggests that the anomalies in the $\mathrm{O}_{3}$ concentration are linked to the anomalies in the cloudiness (or radiation) across Europe during the lockdown period. Figure $2 \mathrm{~b}$ shows that the $\mathrm{O}_{3}$ anomalies follow the same linear relationship with the total cloud cover anomalies for urban as for other environments, which supports the interpretation of a regional scale influence of cloud cover (and therefore solar radiation) on $\mathrm{O}_{3}$ anomalies.

The study accounts for the cloudiness in the $\mathrm{O}_{3}$ against $\mathrm{NO}_{2}$ scatterplot by colouring the dots as a function of the anomalies in the total cloud cover (Figure 2c). The total cloud cover anomalies add another layer of variability on top of this relationship because the distribution of the blue and red dots in the scatterplot seems to follow two parallel lines. A reduced major axis regression is used in order to find the slope and intercept of the line that best summarizes the scatter plot of the $\mathrm{O}_{3}$ anomalies against the $\mathrm{NO}_{2}$ anomalies (Ayers, 2001). The slope obtained restricted to negative total cloud cover anomalies $(-1.75)$ is lower than the slope obtained restricted to positive anomalies $(-1.49)$. This result means that, for the same decrease in $\mathrm{NO}_{2}$ concentration, the increase in $\mathrm{O}_{3}$ concentration is stronger where the cloud cover was reduced (thus, solar radiation was increased). Moreover, the intercept is lower for positive anomalies $(-16.52)$ than for negative cloud cover anomalies (-5.04), which suggests that the concentration of $\mathrm{O}_{3}$ was higher where the cloud cover was reduced. This analysis of the two regression lines shows that the main processes leading to the spatial patterns of the $\mathrm{O}_{3}$ anomalies (Figure 2a), involved solar radiation anomalies.

Radiation and cloudiness have played a major role in $\mathrm{O}_{3}$ 's response to emission reductions. In addition, but to a lesser extent, the advection and subsidence of air masses (with a different level of $\mathrm{O}_{3}$ concentration) could have contributed. Since the correlations between all meteorological variables are high, and nonlinear effects on $\mathrm{O}_{3}$ are expected, it can only be concluded that cloud cover (and radiation) anomalies have largely contributed to the north-southwest contrast observed in the $\mathrm{O}_{3}$ concentration anomalies in Europe during the COVID-19 lockdown.

\section{6 | LEVEL OF TOTAL OXIDANT}

In order to understand the specificity of the $\mathrm{O}_{3}$ response during the lockdown, the spatial and temporal variability of daily mean total oxidant concentrations (i.e. $\mathrm{O}_{\mathrm{x}} \approx$ $\mathrm{O}_{3}+\mathrm{NO}_{2}$ ) is investigated. The study first investigates the spatial patterns of $\mathrm{O}_{\mathrm{x}}$ anomalies at the regional scale (Section 6.1), and then focuses on urban environments, analysing the anomalies in day-to-day variability and in averaged diurnal cycles of $\mathrm{NO}_{2}, \mathrm{O}_{3}$ and $\mathrm{O}_{\mathrm{x}}$ concentrations (Section 6.2).

\section{1 | At the regional scale}

Many processes can be invoked to explain the anomalies in surface total oxidant concentrations: (1) transport and deposition, (2) local photochemical production (thus related to the primary emissions of nitrogen and organic carbon), and (3) loss by oxidation of other atmospheric species (Jacob, 1999). However, a modification in the partitioning between $\mathrm{O}_{3}$ and $\mathrm{NO}_{2}$ 
(a) Berlin (Germany)

(b) London (UK)

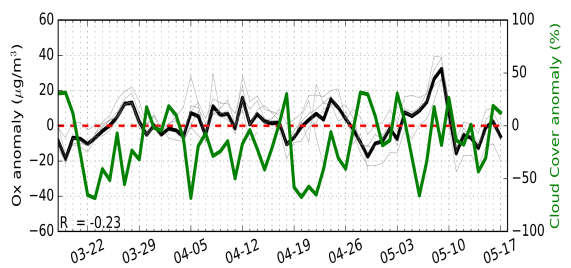

(d) Paris (France)

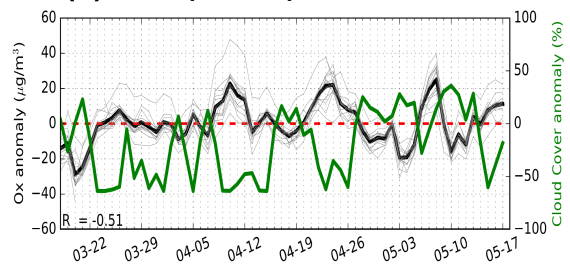

(f) Madrid (Spain)

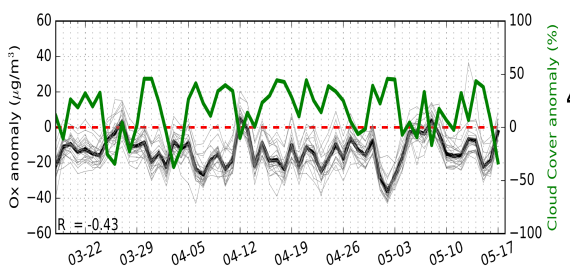

$40^{\circ} \mathrm{N}$

Ox mean concentration an
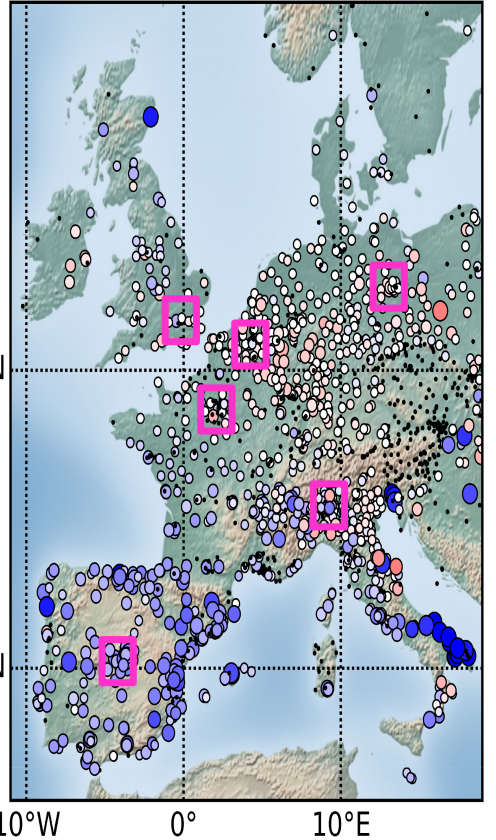

Milan (Italy)

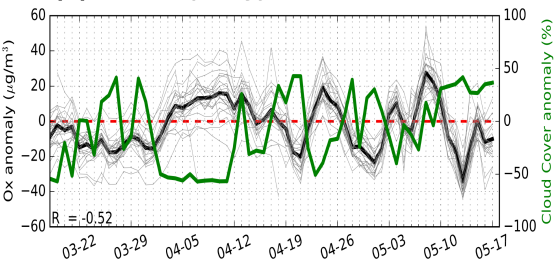

Relative change

- $0 \%$ to $10 \%$

○ $10 \%$ to $20 \%$

o $20 \%$ to $30 \%$

$>30 \%$

$\mathrm{NaN}<30 \%$

F I G U RE 3 Map of mean total oxidant $\left(\mathrm{O}_{\mathrm{x}}\right)$ concentration anomalies at European Air Quality e-Reporting database (AirBase) stations in 2020 compared with the previous seven years (2013-2019) for the period March 18-May 18, 2020. Dots are coloured according to the anomalies in concentration $\left(\mu \mathrm{g} \cdot \mathrm{m}^{-3}\right.$ ) and sized proportionally to the relative change (\%). Black dots correspond to stations with $<30 \%$ of available data. Violet squares correspond to the location of the six major European cities for which are presented the daily total clover cloud anomalies (green line) and daily $\mathrm{O}_{\mathrm{x}}$ mean concentration anomalies compared with the average of the previous seven years at each station (grey lines) and for the average of all stations (black line) in (a) Berlin (Germany), (b) London (UK), (c) Brussels (Belgium), (d) Paris (France), (e) Milan (Italy) and (f) Madrid (Spain)

does not modify the level of total oxidant. The increase in $\mathrm{O}_{3}$ concentrations coinciding with a $\mathrm{NO}_{2}$ decrease is a consequence of the daytime photo-stationary state of $\mathrm{O}_{3}$ (Leighton, 1961) in which the reaction of $\mathrm{O}_{3}$ with $\mathrm{NO}$ (producing $\mathrm{NO}_{2}$ ) is compensated by the photolysis of $\mathrm{NO}_{2}$ (producing $\mathrm{O}_{3}$ ).

Figure 3 presents a map of the mean $\mathrm{O}_{\mathrm{x}}$ concentration anomalies in Europe compared with the previous seven years. In rural areas of Northern Europe (where $\mathrm{NO}_{2}<<$ $\mathrm{O}_{3}$ ), the $\mathrm{O}_{\mathrm{x}}$ anomalies are generally positive but low $(<20 \%)$. The situation is different in Southern Europe. In Southwestern Europe, the $\mathrm{O}_{\mathrm{x}}$ anomalies are strongly negative, reaching $-30 \%$ at several stations. In Italy, they are more variable with values ranging from $-20 \%$ to $20 \%$. In all urban areas (where $\mathrm{NO}_{2} \approx \mathrm{O}_{3}$ ), the anomalies seem to be of the same order of magnitude as in the surrounding rural areas.

\section{2 | In urban environments}

Six major cities located in contrasted regions of the $\mathrm{O}_{3}$ anomaly pattern are selected (Figure 1): Berlin (Germany), London (UK), Brussels (Belgium), Paris (France), Milan (Italy) and Madrid (Spain). Data were collected from all monitoring stations within $\pm 0.5^{\circ}$ of the centre of these cities (that are defined as $13.4^{\circ} \mathrm{E} / 52.5^{\circ} \mathrm{N}$, $0.1^{\circ} \mathrm{W} / 51.5^{\circ} \mathrm{N}, 4.3^{\circ} \mathrm{E} / 50.8^{\circ} \mathrm{N}, 2.3^{\circ} \mathrm{E} / 48.9^{\circ} \mathrm{N}, 9.2^{\circ}$ $\mathrm{E} / 45.4^{\circ} \mathrm{N}, 3.7^{\circ} \mathrm{W} / 40.4^{\circ} \mathrm{N}$, respectively).

Day-to-day variability and diurnal cycle anomalies are calculated for $\mathrm{NO}_{2}, \mathrm{O}_{3}$ and $\mathrm{O}_{\mathrm{x}}$ concentrations as differences with the average of the previous seven years (Figures 3 and 4 and see Figure S7 in Appendix A in the additional supporting information). Anomalies are analysed based on 13 stations in Berlin, eight in London, 26 in Brussels, 31 in Paris, 28 in Milan and 27 in Madrid. 
(a) Berlin (Germany)

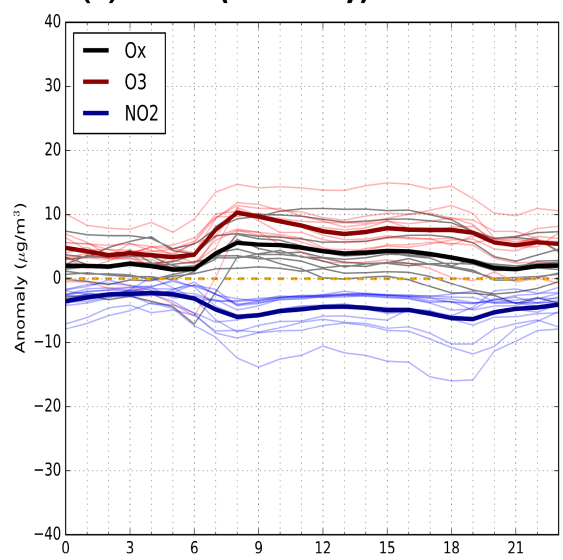

(d) Paris (France)

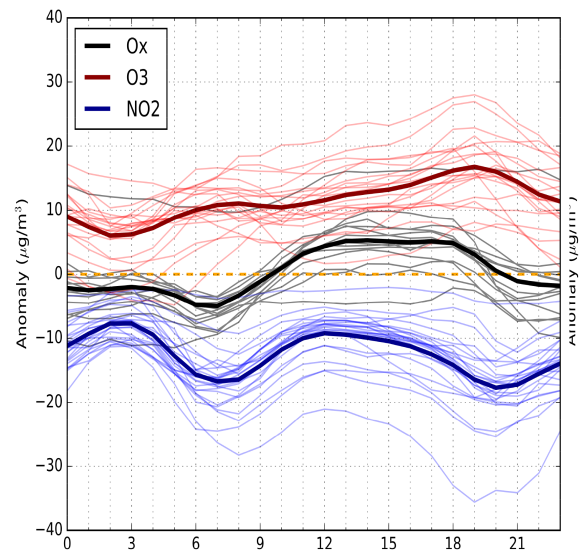

(b) London (UK)

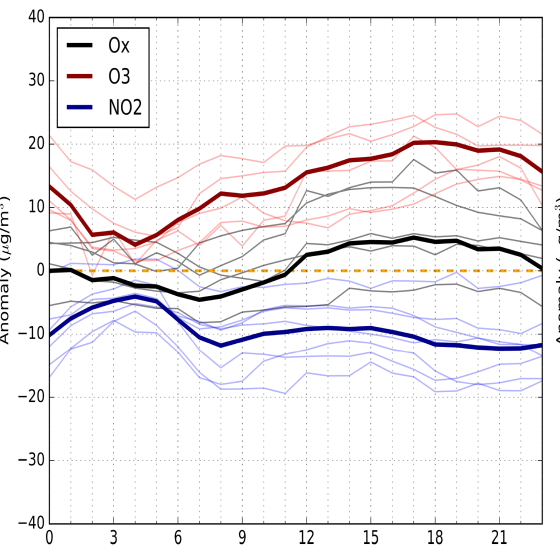

(e) Milan (Italy)

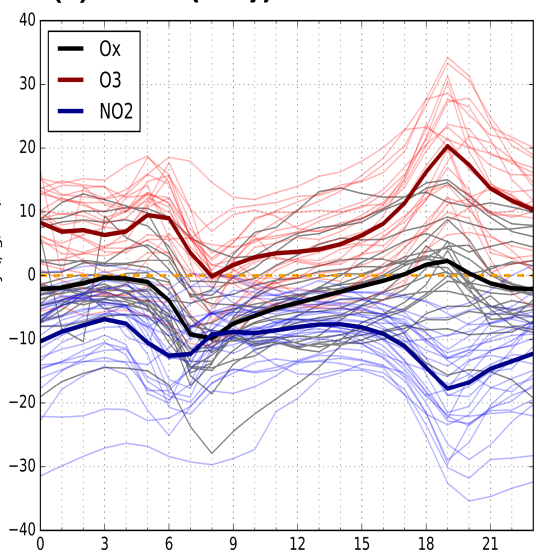

(c) Brussels (Belgium)

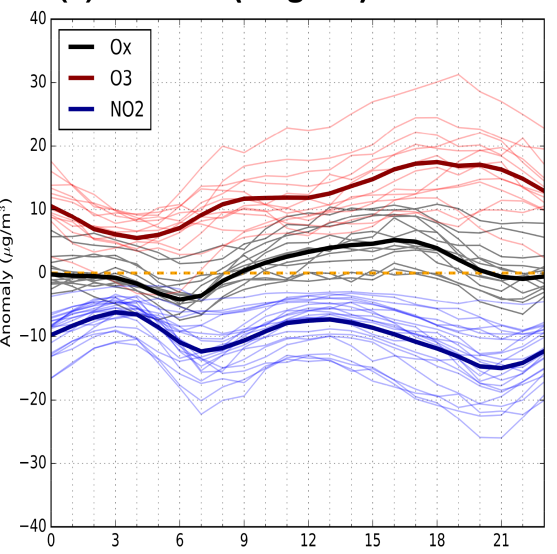

(f) Madrid (Spain)

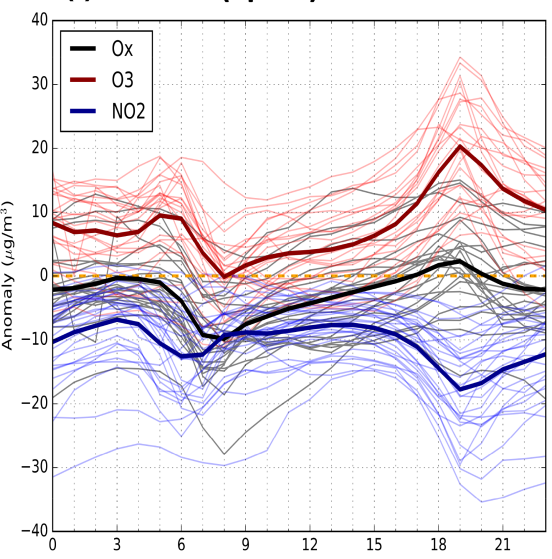

F I G U R E 4 Hourly mean concentration anomalies of nitrogen dioxide $\left(\mathrm{NO}_{2}\right)$ (blue lines) and ozone $\left(\mathrm{O}_{3}\right)$ (red lines) in 2020 compared with the previous seven years (2013-2019) for the period March 18-May 18, 2020, for each monitoring station and for the average of all stations (bold lines) at six major European cities: (a) Berlin (Germany), (b) London (UK), (c) Brussels (Belgium), (d) Paris (France), (e) Milan (Italy) and (f) Madrid (Spain)

In each city, the variability between the individual stations is coherent, so that in the following, the focus is on the city average concentrations (Figures 3 and 4 and see Figure S7 online).

When examining the temporal variability of $\mathrm{O}_{\mathrm{x}}$ in the six cities under consideration (Figure 3), the anomalies compared with previous years are small (typically ranging from -20 to $10 \mu \mathrm{g} \cdot \mathrm{m}^{-3}$ ). Madrid represents an exception with larger negative anomalies (ranging from -30 to $0 \mu \mathrm{g} \cdot \mathrm{m}^{-3}$ ). The periods of negative cloud cover anomaly match well the periods of positive $\mathrm{O}_{3}$ anomaly. The daily total cloud cover anomalies are negatively correlated with the $\mathrm{O}_{\mathrm{x}}$ anomalies, with the correlation co-efficients ranging from -0.23 to -0.52 .

In the major cities of Northern Europe (i.e. Berlin, London, Brussels and Paris), $\mathrm{NO}_{2}$ concentrations decreased and $\mathrm{O}_{3}$ increased during the COVID-19 lockdown period (see Figure S7 in Appendix S1 in the additional supporting information). The $\mathrm{NO}_{2}$ decrease was higher in Paris and Brussels, where lockdown restrictions were stricter than in London and Berlin. In London, the lockdown effect on $\mathrm{NO}_{2}$ concentrations was clearly visible after mid-April. In Milan, the $\mathrm{NO}_{2}$ reduction was associated with a high day-to-day variability of the $\mathrm{O}_{3}$ concentration during the entire period. Compared with the five other cities, Madrid is remarkable because for both $\mathrm{NO}_{2}$ and $\mathrm{O}_{3}$ the anomalies are negative.

Several relatively long periods of more than five consecutive days with negative cloud cover anomalies were observed in all cities, except Madrid. During these periods, $\mathrm{O}_{\mathrm{x}}$ concentrations remained relatively constant and the observed increase in $\mathrm{O}_{3}$ concentration was compensated by the decrease in $\mathrm{NO}_{2}$ concentration. However, the correlation co-efficients between the anomalies in cloud cover and $\mathrm{O}_{\mathrm{x}}$ concentration are variable in the six cities, ranging from -0.06 to -0.42 . This is due to the occurrence of some specific events for which large increases in $\mathrm{O}_{\mathrm{x}}$ reaching $20 \mu \mathrm{g} \cdot \mathrm{m}^{-3}$ were observed during one or two days. Only half of these events were associated with negative cloud anomalies. Other processes 
must therefore be invoked such as the transport of polluted air masses.

The study of the anomalies in the diurnal cycles of $\mathrm{NO}_{2}, \mathrm{O}_{3}$ and $\mathrm{O}_{\mathrm{x}}$ concentrations provides useful information to confirm the authors' interpretation of the evolution of the level of total oxidant (Figure 4). Note that $\mathrm{NO}_{2}$ anomalies remained negative throughout the day and night in all six cities. Except in Madrid, the $\mathrm{O}_{3}$ anomalies remained positive throughout the day. In Berlin, total oxidant anomalies were positive throughout the day and night, ranging between 1 and $5 \mu \mathrm{g} \cdot \mathrm{m}^{-3}$. In London, Brussels and Paris, the total oxidant level decreased overnight (about $-5 \mu \mathrm{g} \cdot \mathrm{m}^{-3}$ ) and increased during the day (about $5 \mu \mathrm{g} \cdot \mathrm{m}^{-3}$ ) compared with the average observed over the previous seven years. In Milan, anomalies were (mostly) negative throughout the day and night, ranging between -10 and $1 \mu \mathrm{g} \cdot \mathrm{m}^{-3}$. In Madrid, during the day and at night the level of total oxidant clearly decreased by $>10 \mu \mathrm{g} \cdot \mathrm{m}^{-3}$.

In conclusion, the concentration of total oxidant decreased during the pandemics in Southwestern Europe, but remained similar to previous (unperturbed) years in Northern Europe. It appears that the observed $\mathrm{O}_{3}$ increase in Northern Europe was due primarily to a change in the partitioning between $\mathrm{O}_{3}$ and $\mathrm{NO}_{2}$ as driven by positive solar radiation anomalies associated with reduced cloud cover. In addition, several episodes of positive $\mathrm{O}_{\mathrm{x}}$ anomalies were noted during a few days, which could be linked to enhanced formation or reduced destruction of $\mathrm{O}_{3}$, or to the transport of polluted air masses.

\section{7 | SUMMARY AND PERSPECTIVES}

The analysis confirms that the COVID-19 lockdown period in Europe has been exceptional in terms of (primary) pollutant concentration change, especially in the case of nitrogen dioxide $\left(\mathrm{NO}_{2}\right)$ whose concentration decrease was at least $14 \%$ for $90 \%$ of the monitoring stations relative to the previous seven years. The ozone $\left(\mathrm{O}_{3}\right)$ concentration response is contrasted between Northern and Southwestern Europe with positive and negative anomalies, respectively. Reduced cloud cover in Northern Europe coincided with the positive $\mathrm{O}_{3}$ anomalies and was associated with a low increase of the level of total oxidant. Enhanced cloud cover in Southwestern Europe coincided with the negative $\mathrm{O}_{3}$ anomalies associated with an important decrease of the level of total oxidant. Radiation and clouds played a major role in $\mathrm{O}_{3}$ 's response to emission reductions. Air mass dynamics may have played a lesser role in the increase in $\mathrm{O}_{3}$ (by advection or subsidence).

Episodes of high total oxidant level were observed in Northern Europe, but an assessment of the role of volatile organic carbons (VOCs) is necessary to quantitatively analyse changes in the chemical regime. Despite the lack of concordance of the anomalies of particulate matter $\left(\mathrm{PM}_{10}\right)$ and $\mathrm{O}_{\mathrm{x}}$, it cannot be excluded that aerosols have played an important role in $\mathrm{O}_{3}$ 's response through the oxidation VOCs, through the production of inorganic aerosols, or through heterogeneous reactions affecting, for example, peroxy radicals $\left(\mathrm{HO}_{2}, \mathrm{RO}_{2}\right)$, formaldehyde ( $\mathrm{HCHO}$, nitrogen oxides (NO) or $\mathrm{O}_{3}$. Chemistrytransport models can provide these answers. Studies based on observations are essential to refine the estimates and to validate model outputs.

The results confirm the significant increase in surface concentrations of $\mathrm{O}_{3}$ observed in most parts of Europe during the lockdown period and reported by Venter et al. (2020) and Ordóñez et al. (2020). Ordóñez et al. attributed this increase primarily to the influence of meteorological parameters rather than to the reduction in the emissions of primary pollutants. The present study concludes that the observed increase in $\mathrm{O}_{3}$ was due primarily to a change in the photochemical partitioning between $\mathrm{NO}_{2}$ and $\mathrm{O}_{3}$ due to an anomalously low cloud cover, while the level of total oxidant remained unchanged, except in the Iberian Peninsula and southwestern France, where it decreased.

Understanding the behaviour of $\mathrm{O}_{3}$ during the COVID-19 lockdown provides an opportunity to design future pollutant reduction regulations with the purpose of reaching the levels of $\mathrm{NO}_{2}$ observed during the lockdown. Nevertheless, the study illustrates the complexity of the processes affecting $\mathrm{O}_{3}$ in the troposphere and, hence, the difficulty of implementing efficient regulations targeting air quality impacts.

\section{ACKNOWLEDGMENTS}

The authors thank Gabriele Pfister, Antonio Caltabiano and Tao Wang for their valuable comments on the manuscript. The National Center for Atmospheric Research is sponsored by the National Science Foundation. The authors are grateful to the European Environmental Agency (EEA) for maintaining and providing the surface concentrations of criteria pollutants over Europe. All data used the study are publicly available at the following repositories: Regulated pollutant concentration measurements "Air Quality e-Reporting" at https://www.eea. europa.eu/data-and-maps/data/aqereporting-8 (permanent link: b21a537e763e4ad9ac8ccffe987d6f77). Meteorological variables "ECMWF CAMS" at https://apps.ecmwf. int/datasets/data/cams-nrealtime. Population density "CIESIN/CIAT 2005 Center for International Earth Science Information Network" at https://doi.org/10.7927/ H42B8VZZ. The study is dedicated to Andreas Hilboll from the University of Bremen who passed away during the COVID-19 pandemics. 
Open access funding enabled and organized by Projekt DEAL.

\section{ORCID}

\section{Adrien Deroubaix (1) https://orcid.org/0000-0003-4464-} 7802

Guy Brasseur (1D) https://orcid.org/0000-0001-6794-9497 Benjamin Gaubert (1D https://orcid.org/0000-0002-65950686

Inga Labuhn (1D https://orcid.org/0000-0003-3755-5264 Laurent Menut (D) https://orcid.org/0000-0001-9776-0812 Guillaume Siour (10) https://orcid.org/0000-0002-5940-4902 Paolo Tuccella (1) https://orcid.org/0000-0003-0951-8773

\section{REFERENCES}

Air Quality e-Reporting (AQ e-Reporting) (2020). Available at https://www.eea.europa.eu/data-and-maps/data/aqereporting8. Permanent link: b21a537e763e4ad9ac8ccffe987d6f77 [Accessed 22 July 2020].

Ayers, G.P. (2001) Comment on regression analysis of air quality data. Atmospheric Environment, 35(13), 2423-2425. https://doi. org/10.1016/S1352-2310(00)00527-6.

Bauwens, M., Compernolle, S., Stavrakou, T., Müller, J.-F., Gent, J., Eskes, H., Levelt, P.F., van der A.R., Veefkind, J.P., Vlietinck, J., Yu, H. and Zehner, C. (2020) Impact of coronavirus outbreak on NO 2 Pollution Assessed Using TROPOMI and OMI Observations. Geophysical Research Letters, 47(11), http:// dx.doi.org/10.1029/2020gl087978.

CIESIN/CIAT. (2005) Gridded Population of the World, Version 3 (GPWv3): Population Count Grid, Future Estimates. Palisades, NY: NASA Socioeconomic Data and Applications Center (SEDAC). https://doi.org/10.7927/H42B8VZZ.Center for International Earth Science Information Network-CIESINColumbia University, United Nations Food and Agriculture Programme-FAO, and Centro Internacional de Agricultura Tropical-CIAT

Colette, A., Andersson, C., Baklanov, A., Bessagnet, B., Brandt, J., Christensen, J.H., Doherty, R., Engardt, M., Geels, C., Giannakopoulos, C., Hedegaard, G.B., Katragkou, E., Langner, J., Lei, H., Manders, A., Melas, D., Meleux, F., Rouïl, L., Sofiev, M., Soares, J., Stevenson, D.S., TombrouTzella, M., Varotsos, K.V. and Young, P. (2015) Is the ozone climate penalty robust in Europe? Environmental Research Letters, 10(8), 084015. https://doi.org/10.1088/1748-9326/10/8/084015.

Derwent, R.G., Manning, A.J., Simmonds, P.G., Spain, T.G. and O'Doherty, S. (2018) Long-term trends in ozone in baseline and European regionally-polluted air at Mace head, Ireland over a 30-year period. Atmospheric Environment, 179(November 2017), 279-287. https://doi.org/10.1016/j.atmosenv.2018.02.024.

Doche, C., Dufour, G., Foret, G., Eremenko, M., Cuesta, J., Beekmann, M. and Kalabokas, P. (2014) Summertime tropospheric-ozone variability over the Mediterranean basin observed with IASI. Atmospheric Chemistry and Physics, 14(19), 10589-10600. https://doi.org/10.5194/acp-14-10589-2014.

Gaubert, B., Bouarar, I., Doumbia, T., Liu, Y., Stavrakou, T., Deroubaix, A.M., Darras, S., Elguindi, N., Granier, C., Lacey, F. G., Müller, J.-F., Shi, X., Tilmes, S., Wang, T. and Brasseur, G.P.
(2020) Global changes in secondary atmospheric pollutants during the 2020 COVID-19 pandemic. Pre-print. https://doi. org/10.1002/essoar.10504703.1.

Goldberg, D.L., Anenberg, S.C., Griffin, D., McLinden, C.A., Lu, Z. and Streets, D.G. (2020) Disentangling the impact of the COVID-19 lockdowns on urban NO2 from natural variability. Geophysical Research Letters, 47(17), 0-3. https://doi.org/10. 1029/2020GL089269.

Inness, A., Ades, M., Agustí-Panareda, A., Barré, J., Benedictow, A., Blechschmidt, A.-M., Dominguez, J.J., Engelen, R., Eskes, H., Flemming, J., Huijnen, V., Jones, L., Kipling, Z., Massart, S., Parrington, M., Peuch, V.-H., Razinger, M., Remy, S., Schulz, M. and Suttie, M. (2019) The CAMS reanalysis of atmospheric composition. Atmospheric Chemistry and Physics, 19(6), 3515-3556. https://doi.org/10.5194/acp-19-3515-2019.

Jacob, D.J. (1999) Introduction to Atmospheric Chemistry. Princeton, NJ: Princeton University press.

Kroll, J.H., Heald, C.L., Cappa, C.D., Farmer, D.K., Fry, J.L., Murphy, J.G. and Steiner, A.L. (2020) The complex chemical effects of COVID-19 shutdowns on air quality. Nature Chemistry, 12(9), 777-779. https://doi.org/10.1038/s41557-020-0535-z.

Le, T., Wang, Y., Liu, L., Yang, J., Yung, Y.L., Li, G. and Seinfeld, J. H. (2020) Unexpected air pollution with marked emission reductions during the COVID-19 outbreak in China. Science, 369, eabb7431. https://doi.org/10.1126/science.abb7431.

Leighton, P.A. (1961) Reactions of Ozone, in Photochemistry of Air Pollution, Vol. 9. New York: Elsevier, pp. 152-183.

Menut, L., Bessagnet, B., Siour, G., Mailler, S., Pennel, R. and Cholakian, A. (2020) Impact of lockdown measures to combat Covid-19 on air quality over western Europe. Science of the Total Environment, 741, 140426. https://doi.org/10.1016/j. scitotenv.2020.140426.

Monks, P.S., Archibald, A.T., Colette, A., Cooper, O., Coyle, M., Derwent, R., Fowler, D., Granier, C., Law, K.S., Mills, G.E., Stevenson, D.S., Tarasova, O., Thouret, V., von Schneidemesser, E., Sommariva, R., Wild, O. and Williams, M. L. (2015) Tropospheric ozone and its precursors from the urban to the global scale from air quality to short-lived climate forcer. Atmospheric Chemistry and Physics, 15(15), 8889-8973. https:// doi.org/10.5194/acp-15-8889-2015.

Ordóñez, C., Garrido-Perez, J.M. and García-Herrera, R. (2020) Early spring near-surface ozone in Europe during the COVID19 shutdown: meteorological effects outweigh emission changes. Science of the Total Environment, 747(December 2019), 141322. https://doi.org/10.1016/j.scitotenv.2020.141322.

Petetin, H., Bowdalo, D., Soret, A., Guevara, M., Jorba, O., Serradell, K. and Pérez García-Pando, C. (2020) Meteorologynormalized impact of the COVID-19 lockdown upon NO2 pollution in Spain. Atmospheric Chemistry and Physics, 20, 1111911141. https://doi.org/10.5194/acp-20-11119-2020.

Shi, X. and Brasseur, G.P. (2020) The response in air quality to the reduction of Chinese economic activities during the COVID-19 outbreak. Geophysical Research Letters, 47(11), e2020GL088070. https://doi.org/10.1029/2020GL088070.

Sicard, P., De Marco, A., Agathokleous, E., Feng, Z., Xu, X., Paoletti, E., Rodriguez, J.J.D. and Calatayud, V. (2020) Amplified ozone pollution in cities during the COVID-19 lockdown. Science of the Total Environment, 735, 139542. https://doi.org/ 10.1016/j.scitotenv.2020.139542. 
Steinbrecht, W., Kubistin, D., Plass-Dülmer, C., Davies, J., Tarasick, D.W., Gathen, P. von der., Deckelmann, H., Jepsen, N., Kivi, R., Lyall, N., Palm, M., Notholt, J., Kois, B., Oelsner, P., Allaart, M., Piters, A., Gill, M., Van Malderen, R., Delcloo, A.W., Sussmann, R., Mahieu, E., Servais, C., Romanens, G., Stübi, R., Ancellet, G., Godin-Beekmann, S., Yamanouchi, S., Strong, K., Johnson, B., Cullis, P., Petropavlovskikh, I., Hannigan, J.W., Hernandez, J-L, Diaz Rodriguez, A., Nakano, T., Chouza, F., Leblanc, T., Torres, C., Garcia, O., Röhling, A.N., Schneider, M., Blumenstock, T., Tully, M., Paton-Walsh, C., Jones, N., Querel, R., Strahan, S., Stauffer, R.M., Thompson, A.M., Inness, A., Engelen, R., Chang, K-L. and Cooper, OR. (2021) COVID-19 crisis reduces free tropospheric ozone across the northern hemisphere. Geophysical Research Letters, 48(5). http://dx.doi.org/10.1029/ $2020 \mathrm{gl091987.}$

Venter, Z.S., Aunan, K., Chowdhury, S. and Lelieveld, J. (2020) COVID-19 lockdowns cause global air pollution declines. Proceedings of the National Academy of Sciences, 5(11), 202006853. https://doi.org/10.1073/pnas.2006853117.

Wang, Y. and Jacob, D.J. (1998) Anthropogenic forcing on tropospheric ozone and $\mathrm{OH}$ since preindustrial times. Journal of Geophysical Research-Atmospheres, 103(D23), 31123-31135. https://doi.org/10.1029/1998JD100004.

Wang, L., Li, M., Yu, S., Chen, X., Li, Z., Zhang, Y., Jiang, L., Xia, Y., Li, J., Liu, W., Li, P., Lichtfouse, E., Rosenfeld, D. and Seinfeld, J.H. (2020) Unexpected rise of ozone in urban and rural areas, and sulfur dioxide in rural areas during the coronavirus city lockdown in Hangzhou, China: implications for air quality. Environmental Chemistry Letters, 18(5), 17131723. https://doi.org/10.1007/s10311-020-01028-3.

Yan, Y., Lin, J., Pozzer, A., Kong, S. and Lelieveld, J. (2019) Trend reversal from high-to-low and from rural-to-urban ozone concentrations over Europe. Atmospheric Environment, 213 (January), 25-36. https://doi.org/10.1016/j.atmosenv.2019. 05.067.

Yu, S. (2019) Fog geoengineering to abate local ozone pollution at ground level by enhancing air moisture. Environmental Chemistry Letters, 17(1), 565-580. https://doi.org/10.1007/s10311-0180809-5.

\section{SUPPORTING INFORMATION}

Additional supporting information may be found online in the Supporting Information section at the end of this article.

How to cite this article: Deroubaix A, Brasseur G, Gaubert B, et al. Response of surface ozone concentration to emission reduction and meteorology during the COVID-19 lockdown in Europe. Meteorol Appl. 2021;28:e1990. https://doi. org/10.1002/met.1990 